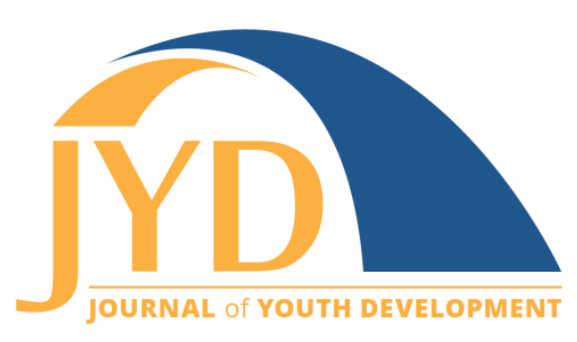

http://jyd.pitt.edu/ | Vol. 16 Issue 4 DOI 10.5195/jyd.2021.975 | ISSN 2325-4017 (online)

\title{
Exploring Camp Policies and Leadership Opinions on Digital Media Use in Camps
}

\author{
Ashley DeHudy \\ Cherry Creek Pediatrics \\ ashley.dehudy@cherrycreekpeds.com \\ Jenny Radesky \\ Department of Pediatrics, Division of Developmental Behavioral Pediatrics; Michigan Medicine \\ jradesky@med.umich.edu
}

Natalie Schellpfeffer

Departments of Emergency Medicine and Pediatrics, Michigan Medicine

nschellp@med.umich.edu

Michael Ambrose

St. Joseph Mercy Health System

michael@docnetwork.org

Andrew Hashikawa

Departments of Emergency Medicine and Pediatrics, Michigan Medicine

drewhash@med.umich.edu

\section{Abstract}

While summer camps provide children a unique experience away from home, this environment may lead to increased and unsupervised use of digital media. Camps' policies and leaderships' views on digital media consumption in camps are currently unknown. To elucidate current trends, we partnered with CampDoc.com to survey a national sample of camp leadership about digital media policies and practices. A single response was selected from each camp and analyzed using descriptive statistics. Free text responses reflecting on positive and negative experiences with digital media were assessed using thematic analysis. We received 722 responses from 363 of the 950 camps within the Camp Doc network. Respondents represented camps in 45 states in the United States. Internet and cell service were available in $22.3 \%$ and $34.7 \%$ of camps, respectively. Approximately $60 \%$ of camps reported a digital media policy for campers and staff. Most policies (67.9\%) did not allow use of digital media devices. Camp leadership reported that smartphones (51.3\%) and social media apps (42.2\%) were most difficult to restrict. Qualitative themes focused on the benefits of digital media for creativity and connection, but also the interruption of camp experiences. Camp personnel described positive media uses aligned with American Academy of Pediatrics media guidelines, for teaching creativity, acquiring new skills, and understanding

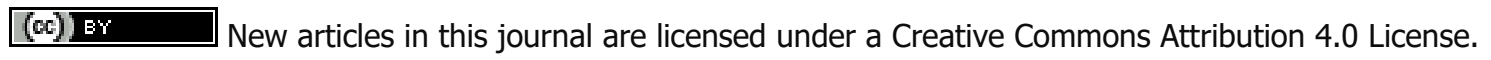
This journal is published by the University Library System, University of Pittsburgh and is cosponsored by the University of Pittsburgh Press. The Journal of Youth Development is the official peer-reviewed publication of the National Association of Extension 4-H Youth Development Professionals and the National AfterSchool Association. 
Journal of Youth Development | http://jyd.pitt.edu/ | Vol. 16 Issue 4 DOI 10.5195/jyd.2021.975

\section{Exploring Camp Policies on Digital Media}

the value of unplugging for creating social connections. Although most camps have policies restricting digital media use, complete restriction may be difficult.

Key words: youth digital media, camp digital media use, benefits of digital media use, downfalls of digital media use

\section{Introduction}

The American Camp Association reports that each year over 14 million American children attend summer camps (Statista, n.d.). These summer camps present an opportunity for adolescents to engage in positive social and emotional experiences away from home by learning new skills and experiencing outdoor activities (Walton et al., 2011). When preparing to attend camps, parents and their children must often decide if digital media devices, such as smartphones, are truly "essential" to bring to summer camp.

Understanding digital media use in summer camp environments is increasingly important because over $95 \%$ of adolescents have access to smartphones, $71 \%$ use multiple social media platforms, and 45\% report being constantly online (Anderson \& Jiang, 2018). A 2016 report on teenagers and digital media found that $50 \%$ of teens felt they were addicted to social media, $72 \%$ reported needing to immediately respond to a text message, and $78 \%$ checked their device hourly (Felt \& Robb, 2016). The American Academy of Pediatrics guidelines recommend consistent time limits for digital media use; however, smartphone use in summer camp settings exclusively for individual recreational use may negate some of the potential beneficial summer camp experiences (MEDIA, 2016b; Uhls et al., 2014).

The decision of whether to bring digital media to camp is further complicated if the summer camp does not have a clear digital media policy for campers. While digital media devices may be needed at camp for using medical devices (e.g., diabetes management), for learning purposes, or for emergencies, the environment away from usual adult supervision and a lack of a clear camp digital medial policy could lead to increased and unsupervised digital media use among campers (Kebede et al., 2019; MEDIA, 2016a, 2016b) that could ultimately distract from or negatively affect camp experiences and social activities. The extent to which summer camps have official written digital media policies and how summer camp leadership view the consumption of digital media in camp settings are currently unknown. To address this knowledge gap, we surveyed a national sample of camp leadership to assess summer camps' policies and practices surrounding digital media and asked camp leadership to describe both negative and positive experiences with digital media that have shaped their camp policies. 


\section{Exploring Camp Policies on Digital Media}

\section{Methods}

We partnered with CampDoc.com, the largest national electronic health records system for camps, to recruit camp leadership to complete an online survey about camp digital media policies, attitudes and practices. Digital media were defined as smartphones with social media and gaming applications, television, video games, tablets, technology wearables and portable gaming devices (MEDIA, 2016a). CampDoc.com has served as the sampling frame for other peer-reviewed studies on health and safety topics related to children attending summer camp (Chang et al., 2017; Kolberg et al., 2020; Schellpfeffer et al., 2017, 2020).

In November 2017, we created and sent a 19-question survey to CampDoc.com, which they then distributed online to all camp leadership within their network of contacts. At the time of the survey, there were 950 camps within the CampDoc.com network. A single response from each camp was selected in order of predetermined importance (1. Director; 2. Owner; 3. Office; 4. Medical Staff; 5. Other Leadership [e.g., pastor]) when multiple responses were received. Survey questions focused on respondent camp demographics, camp digital media policies, identification of digital media devices perceived as most disruptive or difficult to restrict, how camp administration used social media, and camp-specific experiences with digital media. Respondents were also asked to provide free text responses without any identifying information describing positive and negative experiences pertaining to digital media use in camp settings.

Data were collected and organized by CampDoc.com and sent to study authors in a deidentified format in a Microsoft Excel (version 16.035) spreadsheet. Descriptive statistics were used for quantitative analysis. Free text answers were analyzed qualitatively by two different investigators using thematic analysis to identify recurrent themes. As survey research, this study received an exception to informed consent from the university hospital's institutional review board. All quantitative data were analyzed using descriptive statistics using SAS version 9.4.

\section{Results}

Of the available 950 camps, we received responses from 363 camps (38.0\%), representing 45 U.S. states as well as two Canadian provinces. Survey respondents' demographics are shown in Table 1 . Camp directors comprised $61.9 \%$ of respondents. More than half of respondents (55.6\%) had over 10 years of experience working at camps. Respondents were nearly equally distributed between ages 31 and 60 years. Nearly half (44.3\%) of camps identified solely as residential/overnight camp, and $43.9 \%$ were independent and did not have a national affiliation 
Journal of Youth Development | http://jyd.pitt.edu/ | Vol. 16 Issue 4 DOI 10.5195/jyd.2021.975

\section{Exploring Camp Policies on Digital Media}

(e.g., 4-H or Girl/Boy Scouts of America). Most camps (97.0\%) were within 20 miles of police or fire departments, which served as a proxy measure for geographic isolation. Wi-Fi access was available to $22.3 \%$ of campers and cell phone service was available in $34.7 \%$ of camps.

Table 1. Survey Response Demographics

\begin{tabular}{|c|c|c|}
\hline Respondent role & $\begin{array}{c}\text { Frequency } \\
\left(N_{\text {total }}=363\right)\end{array}$ & Percent \\
\hline Director & 225 & $61.9 \%$ \\
\hline Office staff/registrar & 54 & $14.9 \%$ \\
\hline Nurse/doctor & 37 & $10.2 \%$ \\
\hline Other & 12 & $3.3 \%$ \\
\hline Program area leadership & 9 & $2.5 \%$ \\
\hline Owner & 7 & $1.9 \%$ \\
\hline Teacher/counselor & 6 & $1.6 \%$ \\
\hline Upper management & 6 & $1.6 \%$ \\
\hline Health care other field/EMT & 4 & $1.1 \%$ \\
\hline Assistant director & 3 & $0.8 \%$ \\
\hline Age of respondent & $\begin{array}{c}\text { Frequency } \\
\left(N_{\text {total }}=363\right)\end{array}$ & Percent \\
\hline Less than 20 years old & 4 & $1.1 \%$ \\
\hline 20-30 years old & 52 & $14.3 \%$ \\
\hline $31-40$ years old & 103 & $28.4 \%$ \\
\hline $41-50$ years old & 80 & $22.0 \%$ \\
\hline $51-60$ years old & 84 & $23.1 \%$ \\
\hline Older than 60 years old & 40 & $11.0 \%$ \\
\hline
\end{tabular}


Journal of Youth Development | http://jyd.pitt.edu/ | Vol. 16 Issue 4 DOI 10.5195/jyd.2021.975 Exploring Camp Policies on Digital Media

Table 1. (continued)

\begin{tabular}{|c|c|c|}
\hline Respondent years of experience working in camps & $\begin{array}{c}\text { Frequency } \\
\left(N_{\text {total }}=363\right)\end{array}$ & Percent \\
\hline Less than 5 years & 75 & $20.7 \%$ \\
\hline $5-10$ years & 86 & $23.7 \%$ \\
\hline More than 10 years & 202 & $55.6 \%$ \\
\hline Camp type & $\begin{array}{c}\text { Frequency } \\
\left(N_{\text {total }}=363\right)\end{array}$ & Percent \\
\hline Overnight Regular Camp Only & 161 & $44.4 \%$ \\
\hline Regular Day Camp Only & 75 & $20.7 \%$ \\
\hline Not Available & 38 & $10.5 \%$ \\
\hline Both Regular Day Camps and Regular Night Camps & 36 & $9.9 \%$ \\
\hline Medical or Special Needs Camp Only & 28 & $7.7 \%$ \\
\hline Overnight Regular and Medical Camps & 19 & $5.2 \%$ \\
\hline Regular Day, Regular Night, and Medical Camps & 6 & $1.6 \%$ \\
\hline Camp offerings/specialties & $\begin{array}{c}\text { Frequency } \\
\left(N_{\text {total }}=363\right)^{a}\end{array}$ & Percent ${ }^{a}$ \\
\hline Water Activities & 242 & $66.7 \%$ \\
\hline Sports & 217 & $59.8 \%$ \\
\hline Arts & 214 & $58.9 \%$ \\
\hline Adventure & 189 & $52.1 \%$ \\
\hline Environmental & 188 & $51.8 \%$ \\
\hline Academic & 99 & $27.3 \%$ \\
\hline
\end{tabular}

a Camps were able to select more than one choice and so percentages will not add to $100 \%$. 


\section{Exploring Camp Policies on Digital Media}

\section{Digital Media Camp Policies}

Respondents were asked if their camp had any written policy for digital media use. Of camps responding to this question, most reported some sort of digital media policy that applied to either campers or staff (87.0\%). Most camps (60.5\%) reported having a digital media policy for both campers and staff, followed by policies for camp staff only $(17.3 \%)$, policies for campers only $(9.3 \%)$, or no or unknown digital media policies $(12.9 \%)$.

When asked to identify statements most consistent with the camp's digital media policy for campers, $67.9 \%$ of respondents reported campers were not allowed to bring digital media devices to camp or devices were collected at the start of camp, $25.9 \%$ reported campers were allowed to use digital media in designated times and places, 3\% reported campers could bring and use digital media devices without restriction, less than $1 \%$ reported campers could bring digital media devices for special exceptions (e.g., diabetes management) with prior approval from the camp director, less than $1 \%$ reported devices could not be used because of complete lack of any internet or cell phone service, and less than $1 \%$ reported digital media was allowed for camera use only.

Among respondents reporting specific policies for staff use of digital media, $71.6 \%$ reported camp staff were allowed to bring digital media to camp, but could use digital media only at designated times and places; $13.6 \%$ said that staff were not allowed to bring digital media devices with the exception of cell phones for emergency use only; $11.4 \%$ reported that staff could bring digital media devices and use them without restriction; and $3.4 \%$ had various digital media restrictions (e.g., teaching purposes only, prior authorization needed).

\section{Digital Media Devices}

Figure 1 describes digital media devices that respondents reported interfered with camp experiences. The top devices reported to cause interference with the camp experience were portable gaming devices (85.8\%), smartphones (85.8\%), tablets $(76.7 \%)$, and laptops (69.3\%). Figure 2 depicts devices or applications that were reported by survey respondents as most difficult to restrict: smartphones (51.3\%), social media apps $(42.2 \%)$, and wearable devices (35.9\%). 
Journal of Youth Development | http://jyd.pitt.edu/ | Vol. 16 Issue 4 DOI 10.5195/jyd.2021.975

Exploring Camp Policies on Digital Media

Figure 1. Respondents Who Strongly Agreed/Agreed that Campers' Specific Digital Media Devices Interfered with Camp Activities

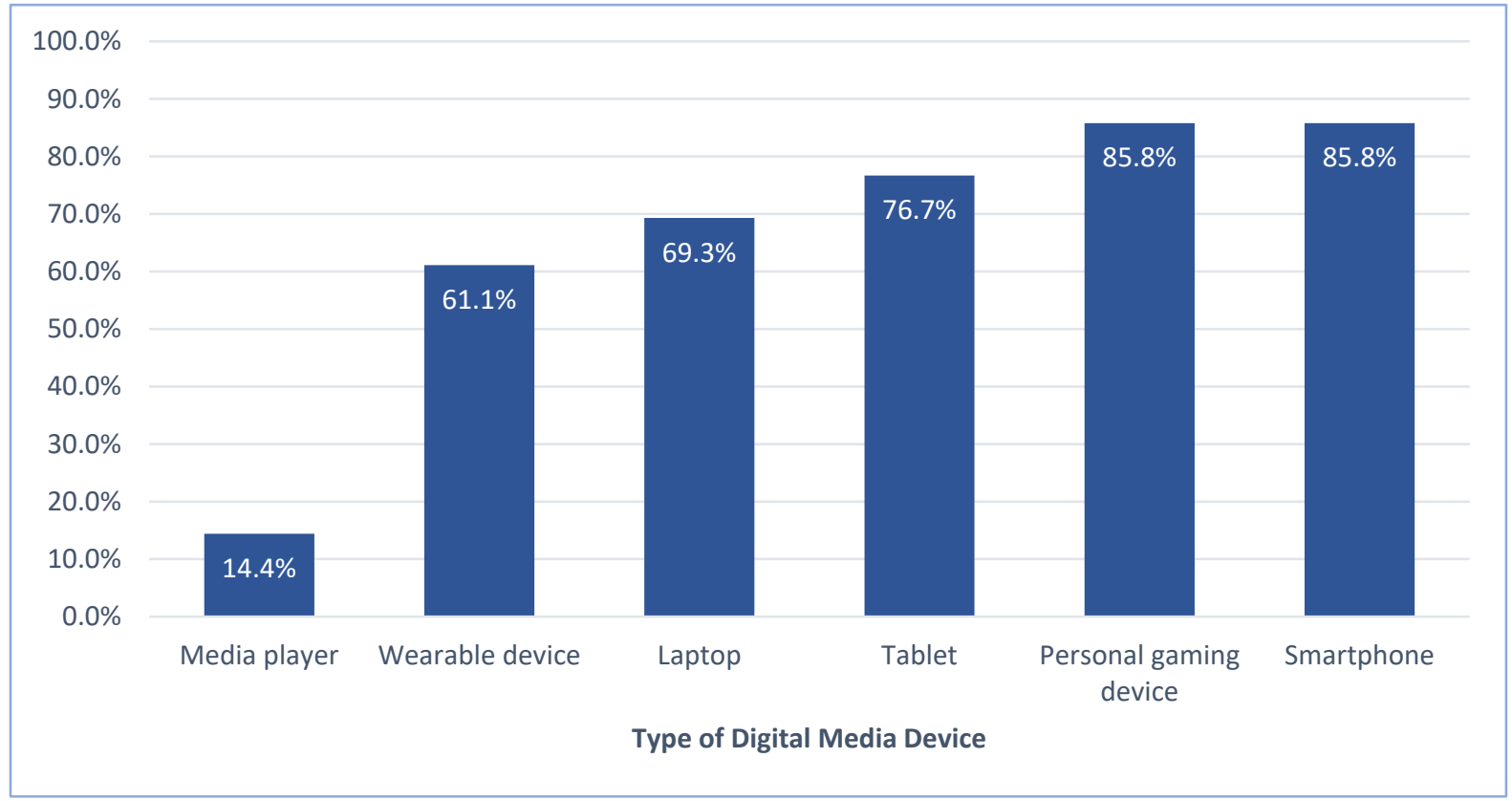

Figure 2. Respondents Who Strongly Agreed/Agreed that Restricting Campers' Specific Digital Media Devices was Difficult

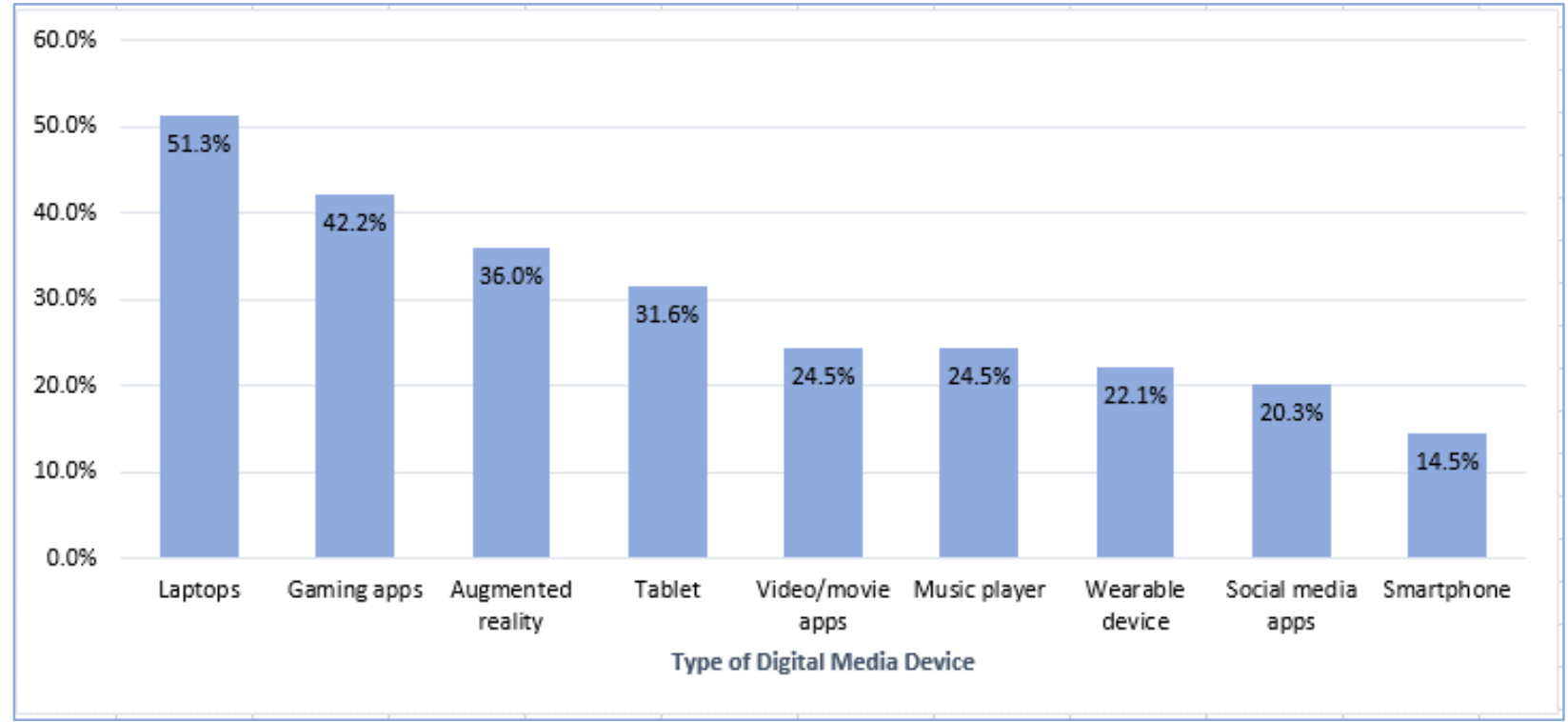


Journal of Youth Development | http://jyd.pitt.edu/ | Vol. 16 Issue 4 DOI 10.5195/jyd.2021.975

\section{Exploring Camp Policies on Digital Media}

\section{Camp Administration Use of Social Media}

To provide updates for families at home or for marketing purposes, many camps reported owning camp-curated social media accounts (79.3\%). A third of these curated social media accounts (31.1\%) were private accounts (e.g., requiring invitation or password), while $68.9 \%$ were public social media accounts. Approximately $15 \%$ of respondents noted that their camp did not have a curated digital media account.

\section{Leadership Responses Describing Experiences with Digital Media}

In total, we received 722 individual survey responses regarding digital media policies from the 363 individual camps. Despite digital media restrictions being in place at most camps, one respondent noted, "campers are not allowed to bring media devices to camp, but we have a very difficult time enforcing this; consequently, many campers have devices with them."

In free text responses, one medically based camp noted that smartphone text option was used frequently for deaf or hearing-impaired staff to communicate. Others reported using devices for "camp-related" activities or teaching purposes, such as using a tuner or metronome application at a music camp, but otherwise restricted use and heavily discouraged use around campers. Some respondents noted staff-specific social media policies that forbade them from taking or posting photos of campers on social media. A few reported that digital media devices could be brought under special circumstances with prior approval (e.g., diabetes management). One camp reported that digital devices serving solely as cameras or music players were allowed.

Survey respondents also wrote about their camp's solutions to achieve either a "screen-free" or "screen-limited" camp environment and the need for clearly communicating to campers and families the digital media policy before the start of camp. Certain camps reported using a "digital media check-in" at arrival where digital media devices were safely stored away until the final day of camp. Some camps ensured campers had access to other modes of restricted communication, including landline-based phones used during designated times and access to email on designated computers at certain times. A majority of camps provided reliable contact information for families, encouraging them to directly contact camp staff through designated channels rather than using camper's own digital media devices or attempting to "sneak" a digital device into their camper's belongings.

At the end of the survey, respondents were invited to share both positive and negative experiences with digital media in summer camps. In qualitative analyses, positive and negative 
Journal of Youth Development | http://jyd.pitt.edu/ | Vol. 16 Issue 4 DOI 10.5195/jyd.2021.975

\section{Exploring Camp Policies on Digital Media}

themes emerged that focused on the benefits of digital media for connection and creativity, as well as the interruption of the camp experience (see Table 2).

Table 2. Distribution of Positive and Negative Responses Concerning Digital Media in Summer Camps

\begin{tabular}{|c|c|c|c|}
\hline $\begin{array}{l}\text { Positive experiences } \\
\text { category }\end{array}$ & Summary of examples & $\begin{array}{l}\text { Frequency } \\
\left(N_{\text {total }}=295\right)\end{array}$ & Percent \\
\hline Camp-curated & $\begin{array}{l}\text { Posting photos of kids for parents to keep } \\
\text { updated, use for marketing }\end{array}$ & 103 & $34.9 \%$ \\
\hline Creative/educational & $\begin{array}{l}\text { Filming videos, taking photos, making } \\
\text { slideshows for campers }\end{array}$ & 72 & $25.1 \%$ \\
\hline Learning to unplug & $\begin{array}{l}\text { Intentionally teaching kids how good it } \\
\text { feels to go without technology }\end{array}$ & 31 & $10.5 \%$ \\
\hline Logistical & $\begin{array}{l}\text { Locating staff, weather updates, } \\
\text { emergency preparation, EMR, } \\
\text { communication }\end{array}$ & 31 & $10.5 \%$ \\
\hline Entertainment & $\begin{array}{l}\text { Video game tournament, music for } \\
\text { relaxation or dance, watch movies }\end{array}$ & 30 & $10.2 \%$ \\
\hline Vulnerable Campers & $\begin{array}{l}\text { Keeping parents updated on illness or } \\
\text { health, homesickness, helping kids with } \\
\text { special needs }\end{array}$ & 14 & $4.8 \%$ \\
\hline Other & $\begin{array}{l}\text { General statements made about digital } \\
\text { media such as, "There has been no } \\
\text { positive evidence exhibited from the use } \\
\text { of these devices." }\end{array}$ & 14 & $4.8 \%$ \\
\hline
\end{tabular}


Journal of Youth Development | http://jyd.pitt.edu/ | Vol. 16 Issue 4 DOI 10.5195/jyd.2021.975

Exploring Camp Policies on Digital Media

Table 2. (continued)

\begin{tabular}{|c|c|c|c|}
\hline $\begin{array}{l}\text { Negative experiences } \\
\text { category }\end{array}$ & Summary of examples & $\begin{array}{l}\text { Frequency } \\
\left(N_{\text {total }}=271\right)\end{array}$ & Percent \\
\hline Camper absent presence & $\begin{array}{l}\text { Lower awareness of surroundings; not } \\
\text { socially engaged; not getting over } \\
\text { homesickness; not sleeping enough; } \\
\text { phobia of social media }\end{array}$ & 64 & $23.6 \%$ \\
\hline Inappropriate use & $\begin{array}{l}\text { Staff "friending" kids under age 18; } \\
\text { posting pictures of minors; inappropriate } \\
\text { pictures taken by campers }\end{array}$ & 55 & $20.3 \%$ \\
\hline Clandestine use & $\begin{array}{l}\text { Counselors don't know how to enforce; } \\
\text { aren't aware child has contact with } \\
\text { parent; child has device for medical } \\
\text { purposes but using for entertainment }\end{array}$ & 50 & $18.5 \%$ \\
\hline Adult distraction & $\begin{array}{l}\text { Digital media distracts adults from } \\
\text { supervising of or engaging with campers }\end{array}$ & 37 & $13.7 \%$ \\
\hline Cause of conflict & $\begin{array}{l}\text { Desired objects cause fights; stolen } \\
\text { devices; not listening to counselors or } \\
\text { staff; being disruptive or bullied; } \\
\text { smartphone being used as camera }\end{array}$ & 24 & $8.9 \%$ \\
\hline Parents as problem & $\begin{array}{l}\text { Calling children in middle of the night; } \\
\text { demanding certain number of pics of child } \\
\text { per day }\end{array}$ & 21 & $7.8 \%$ \\
\hline Other & $\begin{array}{l}\text { General statements made about digital } \\
\text { media such as "Electronics do not belong } \\
\text { at camp." }\end{array}$ & 9 & $3.3 \%$ \\
\hline No issues & & 6 & $2.2 \%$ \\
\hline $\begin{array}{l}\text { Digital media devices not } \\
\text { allowed }\end{array}$ & & 5 & $1.9 \%$ \\
\hline
\end{tabular}




\section{Exploring Camp Policies on Digital Media}

Positive themes using digital media ranged from assisting children with special needs (4.7\%) to serving creative or educational endeavors (24.4\%). The most common positive theme mentioned was camp-curated usage of social media (34.9\%) for marketing and/or sharing updates (i.e., photographs) with families. Several comments were focused on helping campers unplug by intentionally making them aware of separation from digital media and how it affects engagement at camp (10.5\%). Some respondents noted that campers were hesitant at first to be apart from their phones but ultimately appreciated the "social media vacation." One respondent noted, "One of the student's most favorite parts of camp is the restriction of phones and other media. They say that while they were hesitant at first, they truly enjoyed being present with their friends and leaders. They also said that they felt more relaxed and relieved of the pressures that social media creates in their lives." Another respondent commented, "Without use of their phones, we have heard from many campers that it allows them to disconnect and focus on what they are actually participating in, instead of constantly looking at social media or trying to connect with friends who are not at camp."

Negative themes fell into six major categories. The most common theme identified was the category of "camper absent presence" (23.6\%), where campers using devices were not fully able to engage in the camp experience and were preoccupied with media interactions. One respondent wrote, "Cell phones are extremely distracting. Even though kids promise parents that they won't take their phone out of their pocket, they do. Then everyone in camp is more worried about their phone than the poison ivy bush they are about to step in."

Nearly one fifth of respondents (20.3\%) noted that social media was used inappropriately for cyberbullying or posting photos or videos without the permission of others. One person wrote, "Campers are obsessed with social media and do not want to participate because of it (for fear of embarrassment)."

Sneaking digital media into camp-whether to connect with peers or family-was also a problem (18.4\%). In some cases, respondents said that parents were the ones sneaking digital media into their child's belongings for easily accessible communication. Respondents also reported that parents would express frustration with camp leadership for not having enough digital coverage of their child at camp (7.7\%). According to one respondent, "a few times we haven't been able to post the daily photos the next day (perhaps they were posted 2 days later), and we have received rude emails from parents who demanded that we post the photos immediately. Our focus is always $100 \%$ on the campers, keeping them safe, and the program flowing properly, so posting the daily photos sometimes gets delayed. Ten years ago, this 


\section{Exploring Camp Policies on Digital Media}

wasn't an expectation, but because of technology, the expectation has changed and has spoiled the parents a bit."

Adult distraction (13.6\%) was also a common issue, with counselors feeling compelled to sneak off and check their phone rather than focus on camper needs. One respondent noted, "Though smartphones are the easiest way to photograph daily fun, it is also a huge temptation for staff. Even the best counselors have been caught texting, scrolling through social media, or browsing the web unnecessarily when their focus should have been on the campers."

Digital media was the root of conflict in several entries (8.8\%), where respondents reported that media was causing disruption during instruction or delaying camper bedtimes.

\section{Discussion}

Digital media continues to be a prolific challenge in our daily lives. Digital media guidelines reported by camp leadership surveyed within our cohort of U.S. summer camps were variable. Further, both positive and negative experiences were noted amongst leadership regarding digital media in camp settings. Our results have several implications for summer camp digital media policies. Careful consideration should be taken to author policies which foster and reflect ideal camp experience values and clear communication to families and staff prior to the camp start date is necessary.

Families and staff may be more willing to honor policies if emphasis is placed on how restricting digital media allows for an improved camp environment rather than a blanket statement banning use. During development, camp leadership should consider prior research suggesting the benefits of technology restriction. A previous study of a remote summer camp without cell phone service described their camp as a place for human-to-human interaction to allow friendship to grow, encourage teamwork, and enhance a sense of community (Warber et al., 2015).

Camp leadership will also need to clearly detail special considerations for specific digital media use, including use for special medical needs children, for emergency communication or for academic camps requiring technology. Camp social media accounts should also consider privacy concerns related to posting camper's photos, since facial recognition technology can now link child photos to their larger 'digital footprint" (Children's Commissioner, 2018). Resources such as the American Academy of Pediatrics Digital Media toolkit and digital privacy resources may 


\section{Exploring Camp Policies on Digital Media}

inform camp leadership on general digital media principles to consider when crafting their individual summer camp digital media policies that are tailored to the camps' needs (Children's Commissioner, 2018; Common Sense, n.d.; MEDIA, 2016b).

Health care professionals should encourage parents to inquire about digital media policies before attending camps as it may influence camp selection, culture and expectations. If parents and campers are hoping for a rustic camp experience, it may be beneficial to ensure that the camp shares similar goals of being an "unplugged environment." This is in contrast to a more technology-focused camp that may use digital media as a cornerstone of the camp experience. Health care professionals can also assist families in determining what type of camp may be best for their child while emphasizing the importance and health benefits of taking time away from digital media.

While not intuitive to parents, teens may actually welcome a break from technology. Many adolescents have identified their digital media use as a problem and seek assistance in setting limits (Felt \& Robb, 2016). One camp leader noted that when given a choice to assist with digital media policy development, campers nearly unanimously voted for a "device-free" camp.

Summer camps represent an opportunity for the child or adolescent to learn new skills and immerse themselves in new experiences. Campers' lack of engagement from fear of being captured on digital media may stunt new skill development and decrease positive opportunities for character development, including self-confidence, self-esteem, and social relationships (Henderson et al., 2007). Therefore, camps with clear digital media policies and restrictions may help alleviate these fears, as campers may be more willing to try new experiences without the fear of their failure being broadcast online.

Previous research has also demonstrated that adolescents are more prone to depressive symptoms, feel more isolated and/or have decreased self-esteem when using online social networking, experience a decrease in well-being and life satisfaction measures, and have worsening of depressive symptoms with exposure to social media involving social comparisons and feedback-seeking behaviors (Kross et al., 2013; Nesi \& Prinstein, 2015; Pantic et al., 2012). Future studies should include evaluation of both the potential negative and positive effects that digital media has on mental health in the summer camp setting.

Several limitations of our study are worthy of mention. Our survey selected one spokesperson per camp. While this allowed for an equal distribution amongst camps to prevent oversampling, 


\section{Exploring Camp Policies on Digital Media}

it did not allow for more than one view to be expressed per camp, limiting the richness of our data. Given that the survey was released in November, there may also have been a degree of recall bias, as the summer camp season had ended a few months prior. Selection bias is also possible, as respondents may have also been more interested in digital media policies and practices than non-respondents.

Families, campers and camp staff need clear guidelines and expectations for digital media use in summer camps. In our study, there was substantial variability in digital media guidelines for summer camps. Digital media can have both positive and negative effects on the camp community. There is an opportunity for camp leadership in partnership with health care professionals to craft digital media policies that reflect summer camps' core values and assist in strengthening campers' positive experiences.

\section{References}

Anderson, M., \& Jiang, J. (2018). Teens, social media, \& technology 2018. https://www.pewresearch.org/internet/2018/05/31/teens-social-media-technology-2018/

Chang, M., Sielaff, A., Bradin, S., Walker, K., Ambrose, M., \& Hashikawa, A. (2017). Assessing disaster preparedness among select children's summer camps in the United States and Canada. Southern Medical Journal, 110(8), 502-508. https://doi.org/10.14423/SMJ.0000000000000678

Children's Commissioner. (2018). Who knows what about me? A Children's Commissioner report into the collection and sharing of children's data. (2018). https://www.childrenscommissioner.gov.uk/wpcontent/uploads/2018/11/cco-who-knows-what-about-me.pdf

Common Sense. (n.d.). Family media toolkit: Age-based guidelines for children's media and device use. https://www.commonsensemedia.org/aap-toolkitv2

Felt, L. J., \& Robb, M. B. (2016). Technology addiction: Concern, controversy, and finding balance. Common Sense Media.

Henderson, K. A., Bialeschki, M. D., \& James, P. A. (2007). Overview of camp research. Child and Adolescent Psychiatric Clinics of North America, 16(4), 755-767, v. https://doi.org/10.1016/j.chc.2007.05.010

Kebede, M. M., Schuett, C., \& Pischke, C. R. (2019). The role of continuous glucose monitoring, diabetes smartphone applications, and self-care behavior in glycemic control: Results of a multi-national online survey. Journal of Clinical Medicine, \&(1). https://doi.org/10.3390/jcm8010109

Kolberg, K., Saleem, N., Ambrose, M., Cranford, J., Almeida, A., Ichesco, I., Schellpfeffer, N., \& Hashikawa, A. (2020). Pediatric head injuries in summer camps. Clinical Pediatrics, 59(4-5), 369374. https://doi.org/10.1177/0009922819901009 
Journal of Youth Development | http://jyd.pitt.edu/ | Vol. 16 Issue 4 DOI 10.5195/jyd.2021.975

\section{Exploring Camp Policies on Digital Media}

Kross, E., Verduyn, P., Demiralp, E., Park, J., Lee, D. S., Lin, N., Shalblack, H., Jonides, J., \& Ybarra, O. (2013).Facebook use predicts declines in subjective well-being in young adults. PLoS One, 8(8), e69841. https://doi.org/10.1371/journal.pone.0069841

MEDIA, C. O. C. A. (2016a). Media and young minds. Pediatrics, 138(5). https://doi.org/10.1542/peds.2016-2591

MEDIA, C. O. C. A. (2016b). Media use in school-aged children and adolescents. Pediatrics, 138(5). https://doi.org/10.1542/peds.2016-2592

Nesi, J., \& Prinstein, M. J. (2015). Using social media for social comparison and feedback-seeking: gender and popularity moderate associations with depressive symptoms. Journal of Abnormal Child Psychology, 43(8), 1427-1438. https://doi.org/10.1007/s10802-015-0020-0

Pantic, I., Damjanovic, A., Todorovic, J., Topalovic, D., Bojovic-Jovic, D., Ristic, S., \& Pantic, S. (2012). Association between online social networking and depression in high school students: Behavioral physiology viewpoint. Psychiatria Danubina, 24(1), 90-93.

Schellpfeffer, N. R., Leo, H. L., Ambrose, M., \& Hashikawa, A. N. (2017). Food allergy trends and epinephrine autoinjector presence in summer camps. Journal of Allergy and Clinical Immunology: In Practice, 5(2), 358-362. https://doi.org/10.1016/j.jaip.2016.10.018

Schellpfeffer, N. R., Leo, H. L., Ambrose, M., \& Hashikawa, A. N. (2020). Camp leadership perspectives on food allergy-related anaphylaxis events and training for camp staff: A national survey of summer camps. Journal of Allergy and Clinical Immunology: In Practice, 8(4), 1247-1252.e1. https://doi.org/10.1016/j.jaip.2019.11.014

Statista. (n.d.). Number of participants in camping in the United States from 2006 to 2019. https://www.statista.com/statistics/191224/participants-in-camping-in-the-us-since-2006/

Uhls, Y. T., Michikyan, M., Morris, J., Garcia, D., Small, G. W., Zgourou, E., \& Greenfield, P. M. (2014). Five days at outdoor education camp without screens improves preteen skills with nonverbal cues. Computers in Human Behavior, 39, 387-392.

Walton, E. A., Tothy, A. S., \& Health, C. o. S. (2011). Creating healthy camp experiences. Pediatrics, 1274), 794-799. https://doi.org/10.1542/peds.2011-0267

Warber, S. L., DeHudy, A. A., Bialko, M. F., Marselle, M. R., \& Irvine, K. N. (2015). Addressing "naturedeficit disorder": A mixed methods pilot study of young adults attending a wilderness camp. Evidence-Based Complementary A/ternative Medicine, 2015, Article ID 651827. https://doi.org/10.1155/2015/651827 